\title{
Engelli Öğrencilerin Üniversite Eğitimi Sürecinde Karşılaştığı Güçlükler: Van Yüzüncü Yıl Üniversitesi Örneği
}

\begin{abstract}
Abdurrahman MENGí
Öz: Bu araştırma ile Van Yüzüncü Yı1 Üniversitesinde kayıtlı olan engelli öğrencilerin eğitim sorunlarını tespit etmek ve beklentilerini ortaya çıkarmak amaçlanmıştır. Bu çalışma, nitel veri toplama ve değerlendirme tekniklerinin kullanıldığı betimsel bir araştırmadır. Araştırma, Van Yüzüncü Y1l Üniversitesinin kampüsünde bulunan yüksekokul ve fakültelerde eğitim gören toplam 25 katılımcıyla on aylık bir saha çalışması ile gerçekleşmiştir. Araştırmada odak grup ve derinlemesine görüşmeler yoluyla katılımcıların üniversite yaşamlarına dair bilgi, görgü, yaşantı, temel algı ve yaklaşımlarına başvurulmuştur. Katılımcılardan elde edilen veriler betimsel olarak analiz edilmiştir. Elde edilen veriler sorunlar ve beklentiler şeklinde 2 farklı kategoride değerlendirilmiştir. Araştırma bulguları, eğitim-öğretim, beslenme-barınma, erişebilirlik-ulaşabilirlik, akademi-idari personel ve boş zaman gibi farklı alt kategorilere ayrılarak sunulmuştur. Ayrıca araştırma verileri 1şığında çeşitli önerilerde bulunulmuştur. Dolayısıyla bu araştırma, sosyolojik bağlamda çok az incelenmiş bir konuyu ele alması, verilerin ilk elden toplanması, önemli bulgu ve sonuçlara ulaşılması bakımından son derece özgün bir çalışma olmuştur. Ayrıca, sosyolojik bakış açısıyla engelli öğrencilerin üniversite eğitiminde karşılaştığı temel sorunlarına işaret ettiği için de önemli bir çalışma olmuştur. Araştırma sonunda elde edilen bulgular tartışılmış ve ileri araştırmalara yönelik önerilerde bulunulmuştur.
\end{abstract}

Anahtar Kelimeler: Engellilik, Engelli Öğrenci, Üniversite Eğitimi

*Dr. Öğr. Üyesi, Van Yüzüncü Yıl Üniversitesi, Eğitim Fakültesi, Özel Eğitim Bölümü, Email: a.mengi76@hotmail.com, Orcid No: 0000-0001-5903-254X.

Gönderim:14.11.2018 Kabul:04.01.2019 $\quad$ Yayın:15.03.2019




\section{Difficulties Faced by Disabled Students During University Education:}

\section{The Case of Van Yüzüncü Yıl University}

Abstract: The aim of this study is to determine the educational problems of disabled students registered in Van Yüzüncü Y1l University and to reveal their expectations. This study is a descriptive study using qualitative data collection and evaluation techniques. The research was carried out with a field study of 10 months with a total of 25 participants studying in the faculties and colleges in the campus of Van Yüzüncü Yıl University. In the research, the participants` knowledge, experience, basic perceptions and approaches about the university life are collected via focus groups and in-depth interviews. The data obtained from the participants were decrypted analysis. The data were evaluated in two different categories as problems and expectations. Research findings are presented in different sub-categories such as; educationinstruction, nutrition-housing, accessibility-availability, academia-administrative staff and leisure time. In addition, some suggestions were made in the light of research data. Therefore, this research has become a very original study in terms of addressing a subject which has been studied very little in a sociological context, gathering the data from the first hand, and reaching striking findings/results. Also, it has been an important study since it points to the main problems faced by students with disabilities in university education from a sociological point of view. At the end of the research, the findings were discussed and recommendations were made for further research.

Keywords: Disability, Disabled Students, University Education

\section{Giriş}

Geçmişten beri engelli birey hasta, sakat, özürlü gibi etiketlere maruz kaldığı gibi “deli”, "kör”, "topal”, "sağır”, "çolak” gibi kabul sınırlarını aşan ifadeler ile de etiketlenmiştir. Bu tür bir sağlamcı bakış açısı, daha çok "sağlam ve normal bir birey"in varlığını onaylamakta ya da güzel/yakışıklı ve güçlü bir bireyin varlığını daha fazla kabul etmektedir. Sağlamcı bakış açısıyla bireyleri değerlendirmek demek farklı gelişen bireylerin yetersizliğine odaklanarak bireyleri yetersizlikleri üzerinde değerlendirmek demektir (Mengi, 2014). Hâlbuki sosyal modele uygun ve hak temelli bir engellilik tanımının kapsamı farklıdır. Engellilik, herhangi bir nedenle fiziksel, zihinsel, ruhsal ve duyusal yetilerinde belli oranlarda meydana gelen yetersizliklerinden dolayı topluma diğer bireyler ile birlikte eşit koşullarda tam ve etkin katılımı kısıtlanan; toplumun farklı tutum veya bakışından ve çevre koşullarından etkilenen; 
yaşam süreci boyunca çeşitli danışmanlık ve destek hizmetlerine gereksinim duyan bireyleri tanımlamak için kullanılmaktadır.

Sosyolojik perspektifte engellilik, "fiziksel bir durumun ortaya koyduğu gerçeklikten hareketle, sosyal çevreye, sosyal tutumlara, sosyal rollere, sosyal izolasyona ve sosyal bütünleşmeye ağırlık veren bir anlam içermektedir” (Burcu, 1999, s. 84). Sosyolojik perspektifte engellilik, engelli bireylerin fiziksel engellerine odaklanan yaklaşımlardan ziyade engelli bireye yönelik sosyal çevrenin ve toplumsal bakış veya tutumlara ilişkin araştırma ve yaklaşımları ifade eder (Cohen 1994, Lane 1992, Shapiro 1993, Weitz 1996). Ayrıca sosyal çevreden izole olmak, engelli bireylerin diğer bireyler tarafından "hariç tutucu", "yoksun bırakıcı" ve "dışlayıcı" tutumlarına sürekli maruz kalmasını ifade eder (Thomas, Bax ve Smyth, 1989). Bu nedenle, engelli bireye yönelik toplumun olumsuz tutumu veya bakış açısı sosyal izolasyonu körükleyicisi olmaktadır. Younghusband (1970)’e göre, engelli bireyin sosyal ilişkilerinde karşılaştığı sorunlar "potansiyel izolasyon" problemini desteklemektedir. $\mathrm{Bu}$ tür bir izolasyon, engelli bireyin karşılaştığı ve kurtulması zor olan yalnızlık ve sosyal çevreden sürekli uzaklaşma problemidir. Clarke, Riach ve Chyne (1977) ise engelli bireylerin sosyal etkileşiminin zayıf olduğu, yalnızlığı tercih ettikleri ve yaşama dair pasif bir duruş sergilediklerini vurgulamaktadırlar. Toplumun farklı gelişen bireylere yönelik tutumlarını oluşturan dışlanma, ötekileştirme, marjinalleştirme gibi olumsuz tutumlar engelli bireylerde sosyal çatışma ve psikolojik gerilimlere yol açmaktadır. Dolayısıyla sosyolojik çalışmalar, engelli bireylerin sosyal kabulü için, toplumda olumlu alg1 oluşturma, toplumsal duyarlılı̆̆ artırma ve tutum değişikliği yapma hususunda daha etkili olabilir. Böylece toplum, engeli bireyleri ya korunmaya muhtaç görüp onlara acınarak yaklaşmakta ya da onların davranışlarına bakıp onları tehlikeli, saldırgan, güvenilmez görerek onlardan uzaklaşmaktadır. Bazen de toplumun engelli bireylerin davranışlarına tepkisi bakışsal tacizler veya olumsuz tutumlar şeklinde olmaktadır. Toplumun engelli bireylerin davranışlarına yönelik olumsuz bakış ve tutumları, engelli birey ve aileleri için sosyal paylaşım veya yaşam alanlarını yaşanılması güç bir hale dönüştürmektedir (Mengi, 2014). Dolayısıyla toplumun bu tutumları engelli bireyleri sosyal hayatta soyutlayıp izole ettiği gibi bireyin kendi doğasına ve sosyal yaşama yabancılaşmasına da yol açmaktadır. Bu da bireyin ömür boyu yaşamını bir etiketin gölgesinde geçirmesine neden olmaktadır. Böyle bir etiketleme, yetersizliği olan bireylerin belli bir gruba mensup olduğunu tescillemekle kalmaz aynı zamanda bireylerle toplum arasına aşılamaz engeller ya da kapatılması güç mesafeler koymaktadır Eğer engelli birey etiket ve damga ile 
bir kenara itiliyorsa, dışlanıyorsa, marjinalleştiriliyorsa bunun sonucunda toplumda gizli çatışmalar meydana geliyorsa, o zaman toplumsal bütünleşmenin zarar görmesi kuvvetle muhtemeldir (Mengi, 2014).

Toplumsal bütünleşmeyi sağlayan en önemli kurumlardan biri de eğitim kurumlarıdır. Eğitim kurumları temel eğitimden yükseköğrenime kadar çeşitlilik arz etmektedir. Bu araştırma da yükseköğretim kurumlarında biri olan Van Yüzüncü Y1l Üniversitesinde eğitim gören engelli öğrencilere yönelik yapılmıştır. Keza, Türkiye’de yükseköğretim kurumları, üniversitelerin bünyesinde bulunan fakülteler, yüksekokullar, konservatuarlar ve enstitüler gibi birimler aracılığıyla örgün veya yaygın eğitim faaliyetleri gerçekleşmektedir. Üniversiteler, akademik ve mesleki beceriye yönelik eğitim-öğretim faaliyetlerin yürütüldüğü kurumlardır. Dolayısıyla her fakülte ve yüksekokulun bünyesinde birden fazla bölüm ya da ana bilim dalı yoluyla farklı uzmanlık ve meslek alanlarına yönelik öğrenci yetiştirilmektedir.

Türkiye’de öğrenciler, kendi akademik yeterliliğine ve tercihine uygun üniversitelere yerleşmektedirler. Böylece öğrenciler yerleştiği bölüm ve anabilim dalının mevcut programına uygun bir eğitim sürecine katılmış olmaktadır. Ancak, öğrenciler yükseköğrenim kurumlarına kabul edilirken belli standartlara uygun ve eşit koşullarda kabul edilmelerine karşın her öğrencinin öğrenme sürecine katılımı farklılık arz etmektedir. Yani aynı bölüme eşit koşullarda yerleşen öğrencilerin üniversite yaşantısı ve eğitim öğretim süreçlerine katılımı farklı olmaktadır. Ayrıca, her öğrencinin biyo-pisko-sosyal boyutu diğer öğrencilerden farklı olduğu için öğrenciler arasında akademik farklılıklar oluşmaktadır. Diğer bir ifadeyle, eğitim-öğretim süreçlerinde biyolojik, psikolojik ve sosyolojik özellikleri bakımında öğrencilerin sağlıklı veya sağlıksız bir bünyeye sahip olması onların daha başarılı ya da daha başarısız bir dönem geçirmelerine yol açmaktadır. Çünkü yetersizliğine yol açan "psikolojik ve biyolojik gelişmeler sosyal bünyede meydana gelir ki sosyal bünye bu gelişmeleri geciktirici ya da hızlandırıcı rol oynayabilir” (Muuss, 1971, s. 32-33). Bu yüzden engelli öğrenciler, eşit koşullarda üniversitelere yerleşmiş olsa bile çeşitli biyolojik, psikolojik veya sosyolojik farklılığı veya yetersizliği nedeniyle eğitim-öğretim süreçlerine eşit katılım imkânları sınırlıdır. Üniversitede eğitim gören öğrencilerin temel ihtiyaçları büyük oranda benzerlik göstermektedir. Ancak, üniversitelerin; plan, program, donanım, erişebilirlik ve ulaşabilirlik açısından daha çok normal gelişim gösteren öğrencilere uygun olması ve engelli öğrencilerin göz ardı edilmesi, engelli öğrencilerin üniversite yaşamlarında daha fazla güçlükle karşı karşıya kalmasına yol açmaktadır. 
Engelli öğrencilerin eğitim süreçlerine eşit katılımı oldukça önem arz etmektedir. Çünkü eğitim süreçlerine eşit katılan engelli öğrencinin mahalle baskısında kurtulma şans1 yakalamakta ve özgüveni artmaktadır. Ayrıca engelli öğrencilerin mevcut durumundan kaynaklanan "olumsuz etkilerin ve sorunlarının azalması için diğer bireyler gibi eğitim öğretim süreci içerisinde yer alarak bireysel yeteneklerinin geliştirilmesi ve bilgi düzeylerinin artırılması gereklidir" (Sevinç ve Çay, 2017, s. 223). Zira her vatandaşın kendi kabiliyet ve yeterliliğine uygun istediği eğitim kurumunda öğrenim görmesi Türkiye Cumhuriyeti Anayasanın 10. Maddesinde eşitlik ilkesiyle güvence altına alınmıştır.

Dünya Sağlık Örgütü (WHO)'nün verilerine göre dünya nüfusunun yaklaşık yüzde 15'i engelli bireylerden oluşmaktadır. Türkiye'deki engelli bireylerin sayısı ise en son 2002'de Başbakanlık Özürlüler İdaresi Başkanlığının yapmış olduğu araştırma verileri temel alınmaktadır. Bu verilere göre Türkiye nüfusunun yüzde 12,29'u engelli olduğu söylenebilir. Her ne kadar bu nüfusun \% 9,70 süreğen hastalıkları kapsamış olsa da Burcu’nun (1999) da araştırmasında belirtiği gibi "ülke nüfusunun genç bir nüfus olduğu düşünüldüğünde, bu yüzdenin önemli payının gençlere ait olduğu ifade edilebilir (I. Özürlüler Şurası 1999).” Türkiye'de özel eğitim kurumlarında örgün eğitim alan öğrenci sayıları son on yılda önemli oranda artığı görülmektedir. Türkiye'de 2009-2018 eğitim öğretim yılları arasında örgün eğitim hizmetlerinden yararlanan öğrencilere ilişkin veriler Tablo 1'de sunulmuştur.

Tablo 1. 2009-2018 Yılları Arasında Örgün Eğitim Alan Öğrencilere İlişkin Veriler

\begin{tabular}{lllllll}
\hline \multirow{2}{*}{$\begin{array}{l}\text { Öğretim } \\
\text { Yılı }\end{array}$} & \multirow{2}{*}{$\begin{array}{l}\text { Okul } \\
\text { Sayısı }\end{array}$} & $\begin{array}{l}\text { Öğretmen } \\
\text { Sayısı }\end{array}$ & $\begin{array}{l}\text { Özel Eğitim } \\
\text { Okullarında }\end{array}$ & $\begin{array}{l}\text { Özel Eğitim } \\
\text { Sinıflarında }\end{array}$ & $\begin{array}{l}\text { Kaynaştırma } \\
\text { Eğitiminde }\end{array}$ & Toplam \\
\hline $2017-2018$ & 1.395 & 12.846 & 50.025 & 45.815 & 257.770 & 353.610 \\
\hline $2016-2017$ & 1.362 & 12.009 & 48.212 & 42.900 & 242.486 & 333.598 \\
\hline $2015-2016$ & 1.268 & 11.595 & 49.206 & 36.742 & 202.541 & 288.489 \\
\hline $2014-2015$ & 1.254 & 10.596 & 43.796 & 32.265 & 183.221 & 259.282 \\
\hline $2013-2014$ & 1.248 & 9.733 & 40.505 & 29.094 & 173.117 & 242.716 \\
\hline $2012-2013$ & 1.261 & 10.344 & 33.877 & 25.477 & 161.295 & 220.649 \\
\hline $2011-2012$ & 814 & 7.607 & 42.896 & 20.968 & $148 .-753$ & 212.617 \\
\hline $2010-2011$ & 753 & 6.843 & 40.189 & 18.576 & 93.000 & 151.765 \\
\hline $2009-2010$ & 700 & 6.005 & 36.599 & 15.712 & 76.204 & 128.515 \\
\hline
\end{tabular}

Kaynak:http://sgb.meb.gov.tr/meb_iys_dosyalar/2018_09/06123056_meb_istatistikleri_orgun_egitim_2017_20 18.pdf 
Tablo 1'de 2009'da Milli Eğitim Bakanlığı bünyesindeki resmi eğitim kurumlarında toplam 128.515 öğrenci örgün eğitim imkânında yararlana bilirken 2018 yılında ise bu oran neredeyse üç kat artarak 353.610 öğrenciye ulaşılmıştır. Dolayısıyla Türkiye'de her geçen gün engelli bireye yönelik sunulan eğitim-öğretim hizmetlerinin kapsamı artmaktadır. Ayrıca üniversitelerde giderek engelli öğrenci sayılarının artığı gibi onlara yönelik yapılan sınavlarda da bazı tedbirler alınmaktadır. Ölçme Seçme ve Yerleştirme Merkezi (ÖSYM)’nin üniversite yerleştirme sınavlarında engelli öğrencilere yönelik bazı uygulamaları bulunmaktadır. Engelli öğrencilerin engel türünü gösteren belgeler ile sınava başvurması durumunda ÖSYM her engel türüne uygun sınav ortamını oluşturmaktadır. ÖSYM engelli öğrencilerin engel durumuna göre tekli sınav salonlarında okuyucu ve işaretleyici salon başkanı ve gözetmen tayin etmektedir. (ÖSYM, 2017). 2014-2017 eğitim öğretim yılları arasında üniversitelere yerleşmek için sınav başvurusu yapan ve üniversitelere yerleşen öğrenci sayılarına ilişkin veriler Tablo 2'de sunulmuştur.

Tablo 2. Üniversite Sınavları ile İlgili Engelli Öğrenci Sayıları

\begin{tabular}{lllll}
\hline Sınav Yılı & $\begin{array}{l}\text { Başvuran Top. } \\
\text { Öğrenci Sayısı }\end{array}$ & $\begin{array}{l}\text { Yerleșen Top. } \\
\text { Öğrenci Sayısı }\end{array}$ & $\begin{array}{l}\text { Başvuran Engelli } \\
\text { Öğrenci Sayısı }\end{array}$ & $\begin{array}{l}\text { Yerleşen Engelli } \\
\text { Öğrenci Sayısı }\end{array}$ \\
\hline ÖSYM 2017 & 2.265 .844 & 825.397 & 6859 & $\begin{array}{l}\text { 1325 Lisans } \\
\text { 1619 Önlisans }\end{array}$ \\
\hline ÖSYM 2016 & 2.256 .367 & 961.864 & 6015 & $\begin{array}{l}\text { 1278 Lisans } \\
\text { 1545 Önlisans }\end{array}$ \\
\hline ÖSYM 2015 & 2.126 .681 & 983.090 & 4964 & $\begin{array}{l}\text { 922 Lisans } \\
\text { 1333 Önlisans }\end{array}$ \\
\hline ÖSYM 2014 & 2.086 .115 & 922.275 & 3842 & $\begin{array}{l}\text { 729 Lisans } \\
\text { 1172 Önlisans }\end{array}$ \\
\hline
\end{tabular}

Kaynak: https://istatistik.yok.gov.tr/ertş.trh.:04.11.2018

Tablo 2'de 2014 - 2017 yılları arasında üniversite sınavlarına başvuran toplam öğrenci sayıları ve yerleşen öğrenci sayıları ile sınav başvurusu yapan engelli öğrenci sayıları ve üniversitelere yerleşen öğrenci sayıları yer almaktadır. Genel olarak Tablo 2 değerlendirildiğinde Türkiye'de 2017 yılında toplam 2.265.844 öğrenci sınav başvurusunu yapmış ve 825.397 öğrenci üniversitelerin lisans ve önlisans programlarına yerleşmiştir. Ancak bu sayı karşısında üniversite sınavına başvuran ve yerleşen engelli öğrenci sayıları oldukça azdır. Keza 2014 - 2017 yıllarına göre tablo yorumlandığında ise hem sınavlara başvuran hem de üniversitelere yerleşen engelli öğrenci sayıları önemli oranda artığı görülmektedir. Örneğin, 2014 - 2017 yılları arsında sınava başvuran öğrencilerin neredeyse \%50'si üniversiteye yerleşmiş olması son derece önemlidir. Keza Türkiye’deki üniversitelerin, engelli öğrencilere eşit eğitim sunma imkânı sınırlıdır. Bu nedenle çok az sayıda engelli öğrenci üniversitelerde 
rahat okuma imkânına sahip olabilmektedir (Dökmen ve Kışlak, 2004). Türkiye’deki üniversitelerin engelli öğrencilere eşit eğitim imkânı sunma yetersizliğine rağmen son yirmi yılda engelli öğrencilerin üniversite okuma oranında önemli bir artış olmuştur. Örneğin, 1999 yılı ÖSYM verilerine göre, toplam 374 ortopedik engelli öğrenci üniversitelere yerleşmişken, 2016-2017 yılında 13.655 farklı engel türüne sahip engelli öğrenci üniversitelerde eğitim görmesi bu artışın önemli bir göstergesidir. 2016-2017 yılında üniversitelerde okuyan engelli öğrencilerin engellilik durumlarına göre sayıları ise aşağıdaki şekil 1'de verilmiştir.

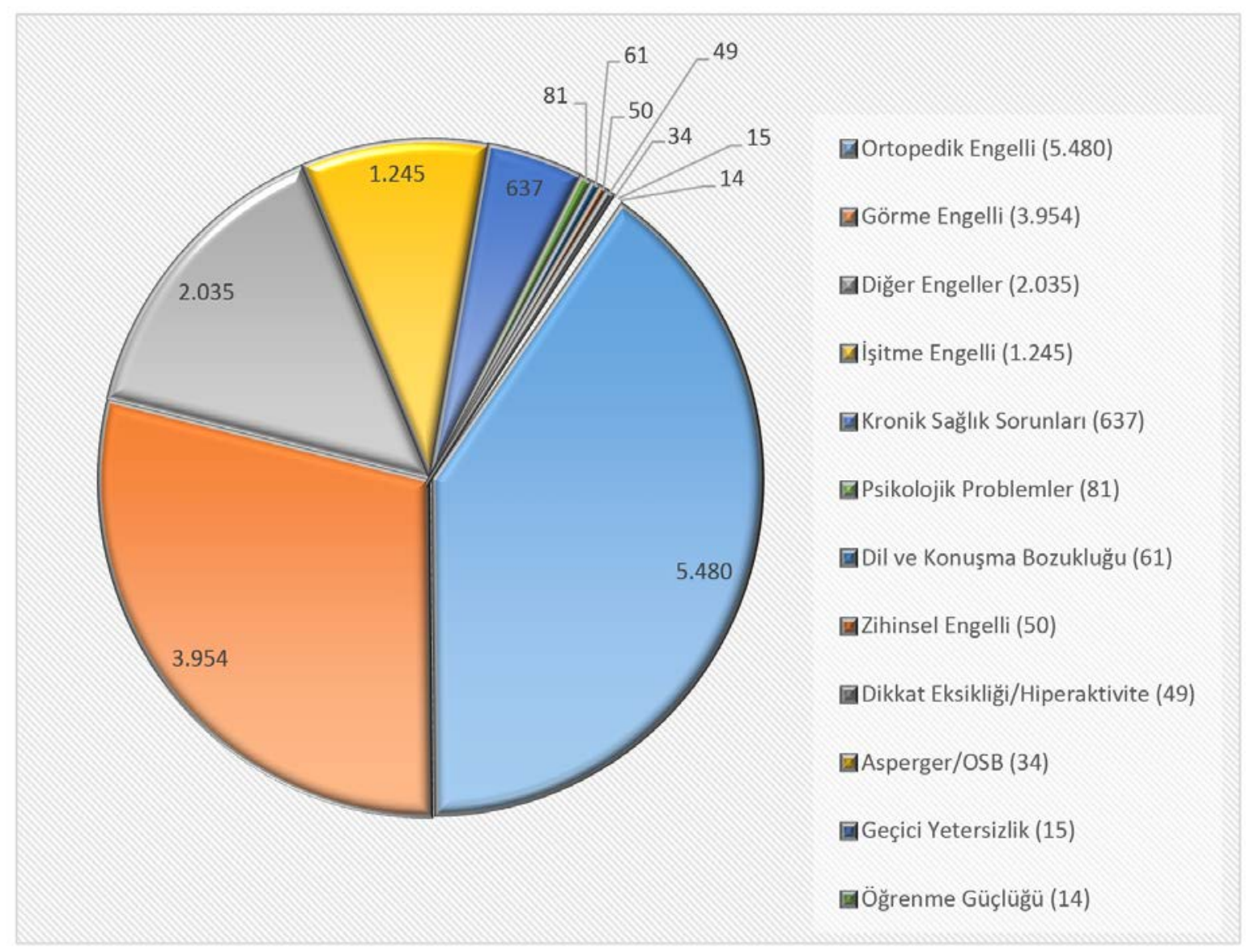

Şekil 1. Engel Durumlarına Göre Üniversitelerde Okuyan Engelli Öğrenci Sayıları

Kaynak ve Not: araştırmacı, (https://istatistik.yok.gov.tr/)’den tarama yapmış ve Yükseköğretim Bilgi Yönetim Sisteminde öğrenci istatistikleri bölümünde engelli öğrenci sayılarına ulaşılmıştır. Araştırmacı öncelikle Van Yüzüncü Yıl Üniversitesi engelli öğrenci sayılarını incelemek isterken sistemde yanlış bilginin olduğunu fark etmiştir. Çünkü araştırmacı Van Yüzüncü Yıl Üniversitesi Engelli Öğrenciler Danışma ve Koordinasyon Birimi Koordinatörü olduğu için ve sayı tespitini birim bünyesinde de yaptığı için önemli bir yanlışın farkına varmıştır. Örneğin, 2018 yılı Ekim ayında araştırmacı resmi bir yazı ve saha araştırması ile Van Yüzüncü Yı1 Üniversitesinin tüm birimlerinde kayıtlı olan dört farklı engel derecesinde 36 engelli öğrenci tespit etmiştir. Diğer taraftan araştırmacı Yükseköğretim Bilgi Yönetim Sisteminde 2018 yılı öğrenci istatistikleri bölümünde ise Van Yüzüncü 
Yı1 Üniversitesinde sadece işitme engelli öğrenci sayısını 95 olarak görünce mevcut sistemdeki veri güvenliği konusunda şüpheye düşmüştür. Bu nedenle araştırmacı, 2 Mayıs 2017'de YÖK tarafindan düzenlenen "Engelsiz Erişim Çalıştayı"na birim koordinatörü olarak katılmış ve YÖK Başkanı tarafında sunulan istatistikleri daha güvenli bulduğu için araştırmasında bu bilgileri kullanılmıştır (http://yok.gov.tr/web/engelsizyok/anasayfa).

Şekil 1'de 14 farklı engellilik durumuna sahip öğrencilerin üniversitelerden okuma imkânına sahip olduğu görülmektedir. Keza engellilik durumlarına göre sayıları en fazla olanlar ise ortopedik engelli, görme engelli, işitme engelli ve kronik sağlık sorunları olan öğrencilerdir. Bunların dışında psikolojik sorunları, dil ve konuşma bozukluğu, zihinsel engelli, dikkat eksikliği ve hiperaktivite bozukluğu, asperger sendromu veya yaygın gelişim bozukluğu, öğrenme güçlüğü gibi daha farklı engel grubuna sahip öğrenciler de üniversite eğitimi almaktadır. Aşağıdaki şekil 2'de ise üniversitelere göre engelli öğrencilerin dağılımı verilmiştir.

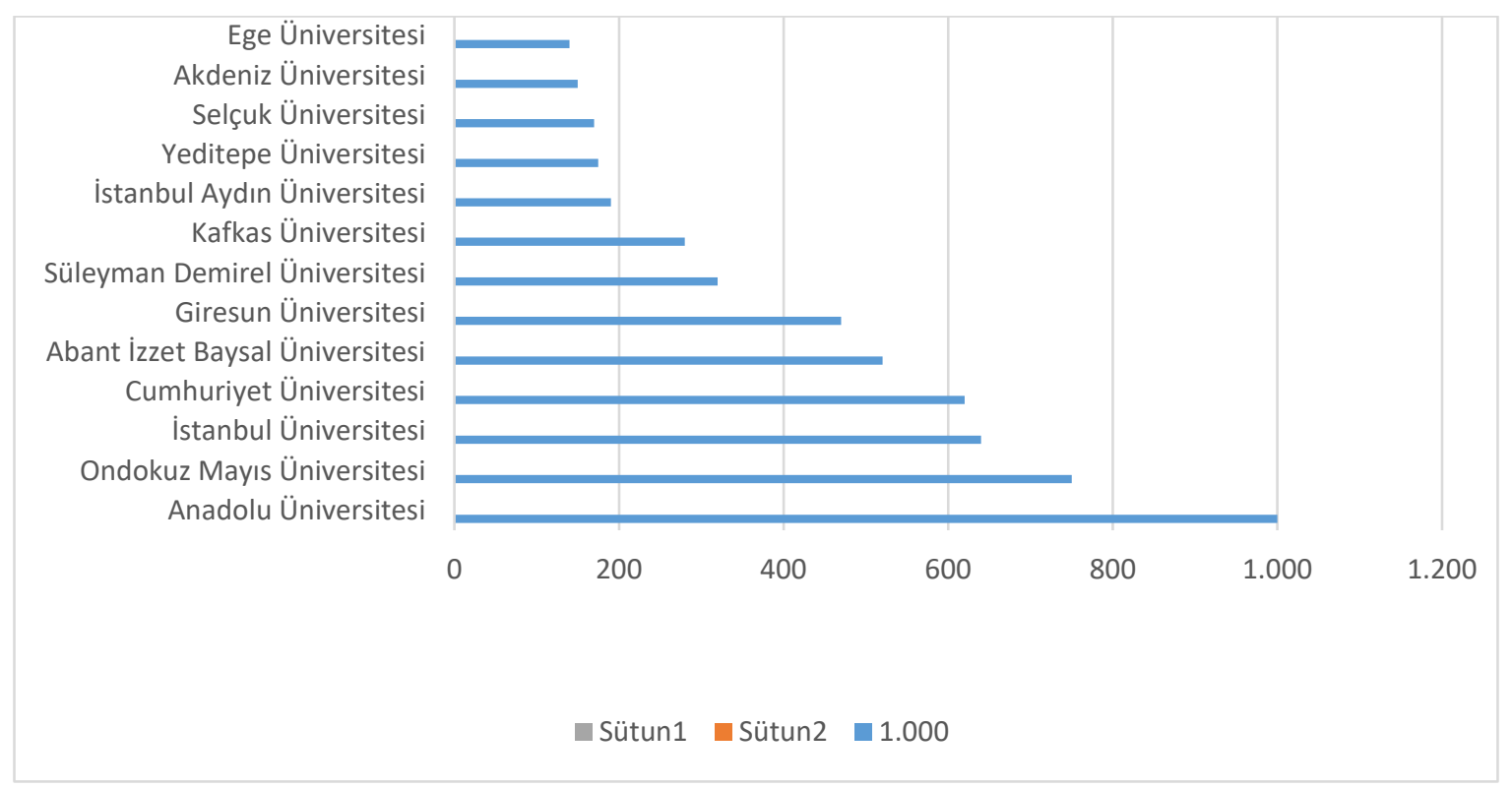

Şekil 2. Üniversitelere Göre Engelli Öğrencilerin Dağılımı

Kaynak: 2 Mayıs 2017’deki YÖK “Engelsiz Erişim Çalıştayı” (http://yok.gov.tr/web/ engelsizyok/anasayfa).

Şekil 2'de engelli öğrenci sayları 100'ün üzerinde olan üniversitelerin öğrenci sayıları grafiğe dâhil edilmiştir. Anadolu üniversitesinde engelli öğrenci sayısı 6.461 olmasına rağmen Türkiye'deki üniversiteler içinde en fazla öğrencisi olan üniversite olma fikrini vermesi için grafikte 1000 olarak gösterilmiştir. 
Son y1llarda engelli öğrencilerin üniversiteye kolay veya daha rahat geçişi için bazı düzenlemeler yapılmaktadır. Ancak engelli öğrencilerin üniversiteyi kazanması ile mevcut sorunları ortadan kalkmıyor. Zira asıl önemli olan engelli öğrencilerin üniversiteyi kazandıktan sonra öğrenim hayatlarının kolaylaştıracak gerekli fiziksel ve akademik ortamın kendileri için makul uyarlanmasıdır. Engelli öğrencilerin eğitim-öğretim süreçlerine etkin ve tam katılımları için iç ve dış mekânlar ile eğitim öğretim faaliyetlerine yönelik gerekli tedbirlerin alınması ve düzenlemelerin yapılması önemlidir. Üniversitelerin fiziksel erişilebilirliğini geliştirmek yani iç ve dış mekânların ulaşılabilirliği, bina içi yatay ve düşey dolaşımın uygunluğu, mekâna ve eğitime erişim (duyarlı/hissedilebilir veya kılavuz zemin ile sinyalizasyon), servis ile ulaşımın sağlanması gerekmektedir.

5378 sayılı kanunun (2005); birinci maddesinde kanunun amacı şu şekilde ifade edilmektedir; "engellilerin temel hak ve özgürlüklerden faydalanmasını teşvik ve temin ederek ve doğuştan sahip oldukları onura saygıyı güçlendirerek toplumsal hayata diğer bireylerle eşit koşullarda tam ve etkin katılımlarının sağlanması ve engelliliği önleyici tedbirlerin alınması için gerekli düzenlemelerin yapılmasını sağlamaktır." Yedinci maddesi ise, "yapılı çevrede engellilerin erişebilirliğinin sağlanması için planlama, tasarım, inşaat, imalat, ruhsatlandırma ve denetleme süreçlerinde erişilebilirlik standartlarına uygunluk sağlanır. Özel ve kamu toplu taşıma sistemleri ile sürücü koltuğu hariç dokuz veya daha fazla koltuğu bulunan özel ve kamu toplu taşıma araçlarının engellilerin erişebilirliğine uygun olması zorunludur. Bilgilendirme hizmetleri ile bilgi ve iletişim teknolojisinin engelliler için erişilebilir olması sağlanır.” (5378 sayılı Kanun, erş. trh.: 04.11.2018).

Dolayısıyla Türkiye'de yükseköğretim kurumlarından eğitim gören engelli öğrencilere yönelik araştırmaların yapılarak bu öğrencilerinin ihtiyaç, beklenti ve sorunlarının tespitine her geçen gün daha fazla ihtiyaç duyulmaktadır. Böylece engelli öğrencilerin eğitim sürecine eşit katılımının önü açılmış olacaktır. Yani engelli öğrencilerin desteğe ihtiyaç duyduğu hususlar belirlenerek, kendisine engel teşkil eden koşular tespit edilerek ve bunların giderilmesine yönelik çalışmalar yapılarak engelli öğrencilere eğitim süreçlerine daha eşit katılım imkânı sunulmuş olacaktır. $\mathrm{Bu}$ nedenle engelli öğrencilere yönelik destek verici hizmetlerin geliştirilmesi ve daha iyi eğitim imkânı sunulması ancak derinlemesine yapılacak saha araştırmaları ile mümkün olmaktadır. Türkiye'de engelli öğrencilerin ihtiyaç ve sorunlarına yönelik sosyolojik literatürde önemli eksikliklerin olduğu bir gerçektir. Sosyolojik literatüre 
katk1 sağlamak ve yükseköğrenimde eğitim gören öğrencilere yönelik hizmet sunulurken belli standartlar eşliğinde hizmet vereceklere 1şık tutmak amacıyla bu çalışma yapılmıştır. Bu genel amaç doğrultusunda aşağıdaki sorulara yanıt aranmıştır:

1- Katılımcıların üniversite eğitimi boyunca engellerinden dolayı karşılaştıkları güçlüklere ilişkin görüşleri nelerdir?

2- Katılımcıların üniversite eğitimi boyunca engellerinden dolayı beklentilerine ilişkin görüşleri nelerdir?

\section{Yöntem}

$\mathrm{Bu}$ çalışma, nitel araştırma desenlerinden olan betimsel desenden hareketle nitel veri toplama ve değerlendirme tekniklerinin kullanıldığı bir araştırmadır.

\section{Araştırmanın Çalışma Grubu}

Araştırmanın çalışma grubu için amaçlı örneklem grubu seçilmiştir. Araştırma, Yüzüncü Y1l Üniversitesinin merkezi kampüsünde bulunan farklı yüksekokul ve fakültelerde eğitim gören, görme, işitme, bipolar ve bedensel engelli öğrenci olan toplam 25 katılımcıyla yapılmıştır. Katılımcıların demografik bilgileri aşağıdaki Tablo 3’te verilmiştir.

Tablo 3. Katılımcıların Demografik Bilgileri

\begin{tabular}{llcc}
\hline Değişkenler & & $\mathbf{N}$ & $\mathbf{\%}$ \\
\hline \multirow{3}{*}{ Yaş } & $19-25$ & 17 & 68 \\
& $26-30$ & 5 & 20 \\
& 31- Üstü & 3 & 12 \\
\hline Cinsiyet & Erkek & 15 & 60 \\
& Kadın & 10 & 40 \\
\hline \multirow{3}{*}{ Eŭitim } & Ön Lisans & 8 & 32 \\
Durumu & Lisans & 14 & 56 \\
& Yüksek Lisans & 3 & 12 \\
\hline \multirow{3}{*}{ Gelir } & Düşük & 20 & 80 \\
Durumu & Orta & 4 & 16 \\
\hline \multirow{2}{*}{ Engel Türü } & Yüksek & 1 & 4 \\
& Ortopedik & 13 & 52 \\
& Görme & 6 & 24 \\
& İşitme & 5 & 20 \\
\hline \multirow{2}{*}{ Engel Derecesi } & Bipolar & 1 & 4 \\
& Hafif & 18 & 72 \\
& Orta & 4 & 16 \\
\hline
\end{tabular}


Tablo 3’teki katılımcı demografik bilgilerine bakıldığında katılımcıların \%60’1 erkek, \%40’1 kadın olduğu, katılımcıların \%68'inin 19-25 yaş aralığında olduğu, \%56'sının lisans eğitimini, \%32'sinin ön lisans eğitimini ve \%3'ünün ise Yüksek Lisan eğitimini aldığını görmektedir. Ayrıca katılımcıların \%80'ninin düşük düzeyde gelir durumuna sahip olduğu, $\% 72$ 'sinin hafif derecede engelli olduğu ve katılımcıların \%52'sinin ortopedik, \%24'ünün görme, \%20’sinin işitme ve \%4’ünün ise bipolar bozukluğuna sahip olduğu görülmektedir.

\section{Veri Toplama Araçları}

Araştırmada nitel veri toplama araçları ve nitel analiz teknikleri kullanılmıştır. Çalışma betimleyici bir araştırma niteliğini taşımaktadır. Araştırmanın veri toplama süreci Eylül 2017'da başlayıp Haziran 2018'de tamamlanmıştır. Yani on aylık bir saha araştırma sürecinin ilk altı ayı odak grup görüşmeleri, sonraki dört aylık süreçte de katılımcılarla yüz yüze görüşmeler gerçekleştirilerek saha verileri toplanmıştır. Ayrıca saha araştırması süresince araştırmacının katılımcılara yönelik yapmış olduğu gözlemler de önemli bir veri toplama aracı olmuştur. Zira araştırmanın kuramsal çerçevesi için ilkin konu ile ilgili literatüre ulaşılmaya çalışılarak yerli ve yabancı literatür incelenmiştir. Böylece üniversitelerden okuyan engelli öğrencilerin sorun ve beklentileri ile ilgili kaynaklar taranmış ve Türkiye'de üniversite okuyan engelli öğrencilerin sorun ve beklentilerine yönelik çok az sayıda araştırmaya ulaşılmıştır. Ayrıca araştırma öncesinden Van Yüzüncü Y1l Üniversitesi Engelli Öğrenciler ile rutin haftalık toplantılarda odak grup görüşmeleri şeklinde öğrencilerin sorun ve beklentileri tartışılmış, olgu odaklı tespitler yapılmış ve belli oranda verilere ulaşılmıştır. Bu nedenle araştırmanın önemi artmış ve araştırma için verilerin önemli bir kısmı saha araştırmasının verilerine dayandırılmıştır. Böylece saha araştırmasının verileri, araştırmanın ilk altı ayı odak grup görüşmeleri neticesinden ve araştırma sürecinde yarı yapılandırılmış görüşme tekniği ile yüz yüze yapılan görüşmeler sonucundan toplanmıştır. Araştırma sürecinde, odak grup ve derinlemesine görüşmeler ve gözlemler yoluyla katılımcıların üniversite yaşamlarına dair bilgi, görgü, yaşantı, temel alg1 ve yaklaşımlarına başvurularak; eğitim-öğretim, beslenme-barınma, erişebilirlik-ulaşabilirlik, akademi ve idari personel ile ilgili karşılaştıkları temel sorunları ve beklentilerinin neler olduğu ortaya çıkartılmaya çalışılmıştır. Keza araştırmada demografik bilgi formundaki temel sorular dışında, araştırma için hazırlanan yarı yapılandırılmış görüşme formunda yer alan katılımcıların sorun ve beklentilerini sondajlayacak 2 adet soru ile verilere 
derinlemesine ulaşılmaya çalışılmıştır. Araştırma sırasında görüşmelerin bir kısmı kayıt cihazı diğer bir kısmı ise katılımcıların doldurmuş oldukları görüşme formu aracılığıyla kayıt altına alınarak veriler elde edilmiştir. Ayrıca araştırmacı katılımcılara yönelik önemli bulguya yol açacak gözlemleri de kayıt altına almıştır. Böylece on aylık süreçte üniversite öğrencilerinin sorunları ve beklentileri tartışılmış ve katılımcıların temel sorun ve beklentilerine ilişsin veriler elde edilmiştir.

\section{Verilerin Analizi}

Araştırmada nitel analiz tekniklerinden betimleyici ve içerik analiz teknikleri kullanılmıştır. Katılımcılardan elde edilen veriler transkript edildikten sonra kodlama, ayıklama, kategorileştirme ve alt kategori şeklinde tasnif edilmiştir. Araştırmada veri toplama aracı olarak kullanılan odak grup ve yarı-yapılandırılmış görüşme formlarında yer alan sorular birer kategori olarak kabul edilmiştir. Araştırma sorularına tepki olarak verilen cevaplar kodlanmış, ayıklama yoluyla sınıflandırılarak alt kategoriler oluşturulmuş ve ilgili soru yani kategori altında sunulmuştur. Analizde ulaşılan kodlar ve alt kategoriler her bir katılımcı için ayrı ayrı gözden geçirilmiş ve veriler arasında karşılaştırma yapılmıştır. Analizler sonucunda toplam 2 farklı kategori oluşturulmuştur. Ayrıca, araştırma verileri, iki ayrı uzman tarafından bağımsız olarak kodlanmış, ayıklanmış ve alt-kategorilere ayrılmıştır. Böylece uzman görüşleri alındıktan sonra araştırmacı ile uzman görüşleri karşılaştırılmıştır. Üçüncü bir uzman görüşü ile de analiz verilerin bir biriyle tutarlı olduğu desteklenmiştir.

\section{Bulgular}

Araştırmada Van Yüzüncü Yıl üniversitesi engelli öğrencilerin üniversitede karşılaştığı sorunlara ve beklentilerine ilişkin temel sorun ve beklentileri iki farklı kategoride incelenmiştir. Katılımcılardan gelen veriler kodlanarak belli kategori ve alt kategorilere bölünmüştür. Bulgular her kategoriye uygun olarak farkl1 alt kategori veya kodlardan hareketle sunulmuştur. Kategori ve alt kategorilere ilişkin bulgular sırayla aşağıda verilmiştir.

\section{Engelli Öğrencilerin Temel Sorunlarına İlişkin Bulgular}

Araştırmanın birinci araştırma problemine ilişkin bulgulara ulaşmak amacıyla katılımcılara "Üniversite eğitiminiz boyunca ne tür güçlükler ile karşılaştınız?" sorusu sorulmuş ve katılımcıların bu soruya verdikleri cevaplar Tablo 4’te araştırmanın bulgularından oluşan veri seti şeklinde sunulmuştur. 
Tablo 4. Engelli Öğrencilerin Temel Sorunları

\begin{tabular}{|c|c|c|c|c|}
\hline $\begin{array}{l}\text { Değişken } \\
\text { Adı }\end{array}$ & $\begin{array}{l}\text { Kodlar } \\
\text { /Sorunlar }\end{array}$ & $\begin{array}{l}\text { Katılıme1 } \\
\text { /Kodlar }\end{array}$ & Görüşler/Altın Örnekler & $\begin{array}{l}\text { Odak Noktalar/ } \\
\text { Kodlama Kuralı }\end{array}$ \\
\hline \multirow{6}{*}{ 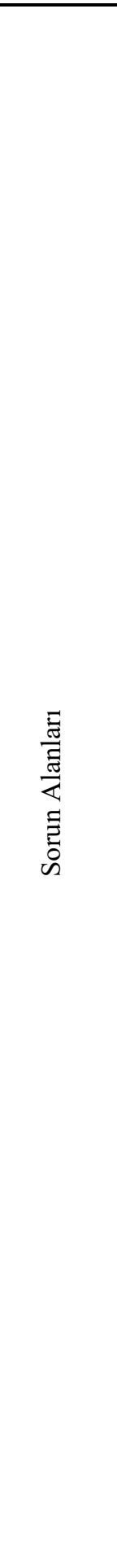 } & $\begin{array}{l}\text { Eğitim- } \\
\text { Öğretim ile } \\
\text { ilgili }\end{array}$ & $\begin{array}{l}\text { K1, K3, } \\
\text { K5, K6, } \\
\text { K7, K9, } \\
\text { K13, } \\
\text { K21, } \\
\text { K22, K25 }\end{array}$ & $\begin{array}{l}\text { "Derste sadece hocayı dinliyorum, yavaş } \\
\text { yazdığım için not tutamıyorum. Sürekli } \\
\text { arkadaşlarımın ders notlart ile idare ediyorum." } \\
\text { "Sinavlarda kodlayıcı ve okuyucuya ihtiyaç } \\
\text { duymaktayım"... "Sinav notlarının fotokopisini } \\
\text { çekecek kadar bile param yoktur"... "Hocalarım } \\
\text { işaret dilini bilmedikleri için onlarla iletişime } \\
\text { geçemiyorum. Dersi anlamadığım konularda } \\
\text { soru sorup cevap alamıyorum. Bu da derslerde } \\
\text { geri kalmama ve sinavlarda başarısız olmama } \\
\text { neden olmaktadır"... }\end{array}$ & $\begin{array}{l}\text { Sinavlarla ilgili } \\
\text { sorunlar. } \\
\text { Ekonomik sıkıntı } \\
\text { İşaret dili }\end{array}$ \\
\hline & $\begin{array}{l}\text { Beslenme } \\
\text { durumu ile } \\
\text { ilgili }\end{array}$ & $\begin{array}{l}\text { K10, } \\
\text { K19, } \\
\text { K23, K24 }\end{array}$ & $\begin{array}{l}\text { "Maddi imkânlarım el vermediği için günde iki } \\
\text { öğ̈̈n yemek yiyorum. Yurda ise ayda } 240 \text { TL } \\
\text { ödüyorum. Bu konuda önemli sorunlar } \\
\text { yaşamaktayım"... "Hocam sizleri Allah } \\
\text { yardımıma gönderdi. Ben o kadar çok ekonomik } \\
\text { sorunlar yaşlyordum ki bilemesiniz. Kısmi } \\
\text { zamanlı bu iş bana ilaç gibi geldi"... }\end{array}$ & Ekonomik sıkıntı \\
\hline & $\begin{array}{l}\text { Barımma } \\
\text { durumu ile } \\
\text { ilgili }\end{array}$ & K8, K13 & $\begin{array}{l}\text { "Ailemin olduğu şehirde okumalıyım. Onların } \\
\text { yanında konaklamalyyım. Başka lüksüm yok." } \\
\text { (K13). }\end{array}$ & Konaklama \\
\hline & $\begin{array}{l}\text { Erişebilirlik- } \\
\text { Ulaşabilirlik } \\
\text { ile ilgili }\end{array}$ & $\begin{array}{l}\text { K4, K8, } \\
\text { K13, K14 }\end{array}$ & $\begin{array}{l}\text { “Kaldığım yurt kampüsün dışında olduğu için } \\
\text { her gün } 2 \text { TL yol parasını ödüyorum. Bu konuda } \\
\text { önemli sorunlar yaşamaktayım”... }\end{array}$ & Ulaşım Ücreti \\
\hline & $\begin{array}{l}\text { Akademik } \\
\text { ve İdari } \\
\text { Personel ile } \\
\text { İlgili }\end{array}$ & $\begin{array}{l}\text { K2, K12, } \\
\text { K16, K24 }\end{array}$ & $\begin{array}{l}\text { "Ben görme engelliyim. Dolayısıyla hocalarımı } \\
\text { dinleyerek not tutamıyorum. Zaman zaman ses } \\
\text { kaydını yapmak istiyorum. Buna da çoğu hocam } \\
\text { izin veremiyor”... }\end{array}$ & $\begin{array}{ll}\text { Ders } & \text { notlarına } \\
\text { erişim. } & \end{array}$ \\
\hline & $\begin{array}{l}\text { Sosyal ve } \\
\text { Kültürel } \\
\text { Uğraşlarla } \\
\text { ilgili }\end{array}$ & $\begin{array}{l}\text { K1, K7, } \\
\text { K9, K20 }\end{array}$ & $\begin{array}{l}\text { "Sinıfimda benimle arkadaşlik edecek kimseyi } \\
\text { bulamıyorum"... }\end{array}$ & Arkadaş edinme \\
\hline
\end{tabular}


Tablo 4’te verilen bulgulardan hareketle engelli öğrencilerin temelde altı farklı sorun alanıyla mücadele ettikleri tespit edilmiştir. Bunlar, eğitim-öğretim, beslenme-barınma ve ekonomik durum, erişebilirlik-ulaşabilirlik, akademik ve idari personel, sosyal ve kültürel uğraşlar ile ilgili temel sorunlar şeklindeki kodlar/sorunlar olarak bulgulanmıştır.

Araştırma neticesinde üniversite okuyan engelli öğrenciler çok farklı alanlarda temel sorunlarla karşılaştığı ortaya çıkmış bulunmaktadır. Ayrıca sadece bir alan da bile engelli öğrencilerin temel sorunlarında önemli farklılaşmanın olduğu görülmektedir. Örneğin, katılımcıların engel oranlarına göre ulaşımla ilgili sorunları değişmektedir. Ortopedik engeli öğrencilerin ulaşımda bazı sorunlar yaşadığı diğer engelli öğrencilerin ulaşımla ilgili pek sorun yaşamadıkları bulgulanmıştır. İşitme engelli bir katılımcı "ulaşımla ilgili pek sıkıntı yaşamıyorum"(K14) derken ortopedik engelli başka katılımcı "engelimden dolayı her yerde ulaşım konusunda sıkıntı yaşıyorum.”(K4). Ayrıca katılımcıların bir kısmı ailesinin desteğine ihtiyaç duyduğu için hem bulunduğu ildeki üniversiteyi seçmek zorunda kaldığını hem de ailesiyle birlikte konaklamak zorunda olduğunu şu şekilde ifade etmektelerdir: “ Valla benim başka üniversitede okuma şansı yok. Bu üniversite benim için zorunludur. Çünkü ailemden ayrı yaşamam çok zor. Birçok konuda desteklerine ihtiyacım var.” (K8). Ailemin olduğu şehirde okumalıyım. Onların yanında konaklamalıyım. Başka lüksüm yok.” (K13). Dolayısıyla engelli öğrenciler daha çok ailelerinde çeşitli destekler aldıkları için ailelerinin bulunduğu yerin dışında okuma imkânları sınırlıdır. Katılımcılardan biri ise "Fakültemde engelli tuvaleti yok. Başka fakülteye gidip lavabo ihtiyacımı karşılıyorum. Ayrıca fakültemin giriş̧ kısmında yağmur yağdı ğında gölet oluşuyor orada arkadaşlarım sekerek (zıplayıp atlayarak) geçebiliyorlar. Ben ise suya girip kendimi ıslatarak geçmek zorunda kalıyorum” (K23) demektedir. Dolayısıyla engelli öğrencilerin kampüs alanında veya kendileriyle ilgili birimlerde belli gereksinimlerini karşılamakta zorlandığı görülmektedir.

Araştırmada bazı engelli öğrencilerin görmediği, işitemediği ve eli çabuk yorulduğu için ders notlarını tutmaktan güçlük yaşadıkları ve sınavlarında zorlandıklarına dair bulgular da elde edilmiştir. "Derslerimde not tutmaya çalışlyorum fakat elim çabuk yorulduğu için zorlanıyorum”(K9). “Derste sadece hocayı dinliyorum, yavaş yazdığım için not tutamıyorum. Sürekli arkadaşlarımın ders notları ile idare ediyorum.” (K25). Dolayısıyla engelli öğrenciler üniversite yaşantılarında kendi engel durumuna göre farklı sorun alanlarıyla karşılaşmaktalar. Her bir öğrencinin temel sorunu faklıdır. Yine her bir engelli öğrenci birden fazla sorunla baş 
etmek zorunda kalmaktadır. Çoğu engelli öğrenci de sürekli desteklerle eğitim hayatında ilerleye bilmektedir.

\section{Engelli Öğrencilerin Temel Beklentilerine İlişkin Bulgular}

Araştırmanın ikinci araştırma problemine ilişkin bulgulara ulaşmak amacıyla katılımcılara "Üniversite eğitiminiz boyunca ne tür beklentiler içine girdiniz?" sorusu sorulmuş ve katılımcıların bu soruya verdikleri cevaplar Tablo 5'te araştırmanın bulgularından oluşan veri seti şeklinde sunulmuştur.

Tablo 5. Engelli Öğrencilerin Temel Beklentileri

\begin{tabular}{|c|c|c|c|c|}
\hline $\begin{array}{l}\text { Değişken } \\
\text { Ad1 }\end{array}$ & Kodlar/Beklentiler & $\begin{array}{l}\text { Katılımc1 } \\
\text { /Kodlar }\end{array}$ & Görüşler/Altın Örnekler & $\begin{array}{l}\text { Odak Noktalar/ } \\
\text { Kodlama Kuralı }\end{array}$ \\
\hline \multirow{6}{*}{ 苛 } & $\begin{array}{l}\text { Eğitim-Öğretim } \\
\text { ile ilgili }\end{array}$ & $\begin{array}{l}\text { K1, K3, } \\
\text { K5, K6, } \\
\text { K7, K9, } \\
\text { K13, } \\
\text { K21, } \\
\text { K22, } \\
\text { K25 }\end{array}$ & $\begin{array}{l}\text { "Sinavlarda bize kodlayıcı ve okuyucu } \\
\text { desteğinin sağlanmasını istiyoruz"... "Yeni } \\
\text { yapılan kütüphanemizin bilgiye erişebilirlik } \\
\text { konusunda özellikle görme engellilere uygun } \\
\text { yapılmasını istiyoruz"... "Bilgiye erişimde } \\
\text { eşit uygulamaları artırlmasını talep } \\
\text { etmekteyiz"... }\end{array}$ & $\begin{array}{l}\text { Sinavlar, } \\
\text { Kütüphane, } \\
\text { Bilgi }\end{array}$ \\
\hline & $\begin{array}{l}\text { Beslenme- } \\
\text { Barınma ile ilgili }\end{array}$ & $\begin{array}{l}\text { K10, } \\
\text { K19, } \\
\text { K23, } \\
\text { K24 }\end{array}$ & $\begin{array}{l}\text { “Özellikle ö̈̆len yemeklerimizin dijital kart } \\
\text { sistemiyle ücretsiz verilmesi ve kampüs ile } \\
\text { merkez arasında çalışan tüm servis araçların } \\
\text { bizleri ücretsiz taşıması lazım”... "Bizler } \\
\text { ihtiyaç sahibiyiz hocam dilenci değiliz. Çoğu } \\
\text { zaman iki ögünle yetiniyorum"... }\end{array}$ & $\begin{array}{l}\text { Ücretsiz } \\
\text { beslenme } \\
\text { ulaşım }\end{array}$ \\
\hline & $\begin{array}{l}\text { Farkındalık } \\
\text { Çalışmaları İle } \\
\text { İlgili }\end{array}$ & & $\begin{array}{l}\text { "İnsanların bizlere yönelik bakış açısının } \\
\text { değissmesi için farkındalık çalışmaların } \\
\text { yapılmasını istiyoruz"... }\end{array}$ & Farkındalık \\
\hline & $\begin{array}{l}\text { Erişebilirlik } \\
\text { Ulaşabilirlik ile } \\
\text { ilgili }\end{array}$ & $\begin{array}{l}\text { K4, K8, } \\
\text { K13, } \\
\text { K14 }\end{array}$ & $\begin{array}{l}\text { "Kampüs içindeki tüm kaldırım, bina, } \\
\text { merdiven, lavabo, derslik gibi alanlara } \\
\text { sorunsuz erişmek istemekteyiz"... }\end{array}$ & Erişimim \\
\hline & $\begin{array}{lll}\text { Boş } & \text { Zaman } & \text { İle } \\
\text { İlgili } & & \\
\end{array}$ & $\begin{array}{l}\text { K1, K7, } \\
\text { K9, K20 }\end{array}$ & $\begin{array}{lrr}\text { "Boş zamanlarımızda } & \text { eğlenip } \\
\text { dinlenebileceğimiz, çevremizdeki diğer } \\
\text { ögrenci arkadaşlarımızla tanışacağımız ve } \\
\text { kültürlenebileceğimiz } & \text { ortamların } \\
\text { oluşturmasın istiyoruz"... } & \end{array}$ & Boş zaman \\
\hline & $\begin{array}{l}\text { Akademik ve İdari } \\
\text { Personel ile İlgili }\end{array}$ & $\begin{array}{l}\text { K2, K12, } \\
\text { K16, } \\
\text { K24 }\end{array}$ & $\begin{array}{l}\text { "Bence görme ve işitme engelli arkadaşlarım } \\
\text { için hocalarımı ile ögrenci işlerinde çalışan } \\
\text { memurların uygun hizmet ve bilgi vermeleri } \\
\text { gerekir"... }\end{array}$ & $\begin{array}{l}\text { Hocalarımız ve } \\
\text { Öğrenci işleri }\end{array}$ \\
\hline
\end{tabular}

Tablo 5’te verilen bulgulardan hareketle engelli öğrencilerin temelde altı farklı beklenti içinde oldukları tespit edilmiştir. Bunlar, eğitim-öğretim, beslenme-barınma, farkındalık çalışmaları, erişebilirlik-ulaşabilirlik, boş zaman, akademik ve idari personel ile ilgili temel 
beklentiler şeklindeki kodlar/beklentiler olarak bulgulamıştır. Dolayısıyla engelli üniversite öğrencileri çok farklı sorunların çözümü için farklı beklentiler içinde olduğu bulgulamıştır. Katılımcıların bir kısmı mevcut durumlarından oldukça memnu kaldıkları gelecekle ilgili bir beklenti içinde olmadığı bulgulamıştır. “Benim şuan üniversitede olmam ve diğer engellileri düşündüğümde burada eğitim almam gayet güzel, çünkü bir zamanlar hayal bile edemediğim bir üniversite hayatım var. Dolayısıla halimden oldukça memnunum” (K15). Diğer taraftan katılımcıların çoğu ise kendi gelecekleriyle ilgili kaygı duydukları, işsizlik korkusu yaşadıkları bulgulamıştır. “Doğrusu ben geleceğimden kaygılıyım, yarının ne olacă̆ını hiç kimse bilmez. Üniversite sonrasında iş bulabilir miyim emin değilim. Benim tek isteğim ilerde memur olup yaşamımın geri kalanını daha rahat sürdürmemdir” (K21). Böylece araştırmada her bir katılımcını geleceğe dair beklentisinin farklı olduğu gerçeği ortaya çıkmıştır.

\section{Tartışma ve Sonuç}

Araştırma bulguları çerçevesinde oluşturulan veri setinden hareketle engelli üniversite öğrencilerin eğitim süreçlerinde yaşadıkları sorunlar ve beklentileri ile ilgili bazı sonuç ve beklentilere ulaşılmıştır. Araştırmanın sonuçları alanyazındaki çalışmalar ile karşılaştığında; ilgili literatür tarandığında Türkiye'de bu hususta yapılan ilk araştırma Burcu’nun (1999) “Üniversitede Okuyan Özürlü Öğrencilerin Sorunları: Hacettepe-Beytepe Kampüsü Öğrencileri Örneği” adlı çalışmasıdır. Bu araştırmada üniversite öğrencilerinin temel sorun ve beklentileri; "eğitim-öğretim, beslenme-barınma, erişebilirlik-ulaşabilirlik, akademi ve idari personel” gibi alt kategoriler şeklinde tespit edilmiştir. Diğer bir çalışma ise Sarı'nın (2005)'te yaptığ1 "Selçuk Üniversitesinde Öğrenim Gören Bedensel Engelli ve Görme Engelli Öğrencilerin Karşılaştıkları Sorunlar ve Çözümüne Yönelik Çağdaş Öneriler” adlı çalışmasıdır. Araştırma bedensel ve görme engelli öğrencilerin üniversitede önemli sorunlar yaşadıklarına dikkat çekerek mevcut sorunları öneri sunmaktadır. Bu konuda yapılan son araştırma ise, Sevinç ve Çay'ın (2017), "Fiziksel Engelli Bireylerin Üniversite Eğitimi Sırasında Karşılaştıkları Sorunlar (Akdeniz Üniversitesi Örneği)” adlı çalışmadır. Bu araştırmada fiziksel engelli öğrencilerin üniversite eğitimi esnasında fiziksel şartlarla, ulaşım ve erişimle ilişkili daha çok sorunlar yaşadığı sonucuna ulaşılmıştır. Dolayısıyla Türkiye'de engelli öğrencilerin temel sorun ve beklentilerine yönelik yapılan araştırmalar son 20 yıldır yapılmasına rağmen bu konudaki araştırmanın oldukça az olması dikkat çekmektedir. Keza, 
çok yavaş da olsa Türkiye sürekli gelişen bir ülke olduğu için özellikle son 20 yılda Türkiye'deki üniversiteleşme oranında ve üniversitelerin fiziki ya da hizmet anlayışında da önemli oranda değişim ve dönüşüm yaşand1. Bu nedenle Burcu'nun 20 yıl önce Ankara’da yapmış olduğu araştırmanın sonuçları ile 20 yıl sonra Van'da yaptığımız bu araştırma ile üniversitede okuyan öğrencilerin temel sorun ve beklentileri arasında anlamlı bir fark olduğu gibi önemli oranda benzer sonuçların da olduğu görülmektedir. Her iki araştırma da engelli öğrencilerin üniversite eğitimlerinde hem fiziki mekânda hem de bilgiye erişimde önemli oranda güçlükler yaşadığını, özellikle işitme engelli öğrencilerin öğretim elemanları ve idari personellerle iletişim kurmaktan zorlandıkları gibi benzer sonuçlara ulaşılmıştır. Ancak bu araştırmanın önceki araştırmalardan önemli oranda farklı sonuçları da olmuştur. Keza, Van Yüzüncü Yıl Üniversitesi sosyo-ekonomik ve akademik düzeyi düşük öğrencilerin tercih ettiği bir üniversite olduğu için engelli öğrenciler sorun ve beklentilerini ifade ederken daha çok temel ihtiyaçları yani maddi ihtiyaçlarını temele alarak görüş beyan etmeleri asıl sorunlarının anlaşılmasına katkı sunan az oranda veriye ulaşılmıştır. Bu durum da araştırmacının gözlem ve görüşmeleri neticesinde elde ettiği bulgu ve sonuçların geniş bir zamanda ancak elde edilmesine yol açmıştır. $\mathrm{Bu}$ araştırmada ulaşılan sonuçları, araştırma bulgularında uyulan sistematiğe göre aşağıda sunulmuştur.

Van Yüzüncü Yıl Üniversitesinin merkezi kampüs yerleşkesinin iç ve dış mekânları erişilebilirlik açışında ortopedik ve görme engelli öğrenciler için yer yer sorun teşkil ettiğini, görme ve bedensel engelli öğrencilerin kaldırımlarda yürürken çeşitli engeller ile karşılaştıkları, bazı binaların rampaları uygun olmadığı, merdiven ve asansörlerin engelli bireylerin erişimine uygun olmadığı, bina içerisinde engelli bireylere uygun lavaboların olmadığına dair sonuçlara ulaşılmıştır.

Ayrıca işitme engelli öğrencilerin karşılaştıkları sorunlarının başında öğretim elemanlarının işaret dilini bilmemesi ve derslerini anlatırken işitme engelli öğrencinin durumunu göz önünde bulundurmamasıdır. Dolayısıyla işitme engelli öğrenciler üniversite eğitimlerinde eşit şartlarda eğitim imkânından yararlanmadığı halde sınıf arkadaşlarıyla aynı dersin sınavına katılmak zorunda kalmaktalar. Sınav sonucunda da başarısız olması kaçınılmaz olmaktadır. Bu durum da işitme engelli öğrencilerin eşit eğitim hakkına erişimde maruz kaldığı haksız bir uygulamaya işaret etmektedir. Ayrıca üniversitenin hiçbir sınıf, amfi ve konferans salonunun uygun olmadığı yani işitme cihazı veya koklear implant kullanıcılarının erişilebilirliğini artırmak için İD (indüksiyon döngü sistemi) ve FM (Frekans Modülasyonu) 
sisteminin bulunmaması da ayrı bir sorun olarak işitme engeli öğrencilerin karşısına çıkmaktadır. Diğer taraftan hem işitme hem de görme engelli öğrenciler için öğretim elemanının ders anlatımında not tutmaları da ayrı birer sorun olarak durmaktadır. Çünkü görme engelli öğrenci öğretim elemanının tahtaya yazdığı yazıyı göremediği için ders notunu alamazken işitme engelli öğrenci de öğretim elemanının konuşmasını duyamadığı için ders notunu alamamaktadır. Böylece her iki öğrenci grubu da sınıf içi etkinlikler ve derse katılımı ile ilgili önemli sorunlar yaşamaktadırlar. Ayrıca öğrenciler sınavlarla ilgili sorunlar da yaşanmaktadır. Sınavlarda özellikle görme, işitme ve psikolojik sorunları olan öğrenciler okuyucu, kodlayıcı, engellerine uygun sınav ortamı gibi sorunlar yaşadığı tespit edilmiştir.

Yüzüncü yıl üniversitesinde öğrenim gören engelli öğrencilerin diğer bir sorunu ise kendi birimlerinin idari personelleri ile ilgilidir. Özellikle öğrenci işlerinde hizmet veren personellerin işaret dilini bilmediği için işitme engelli bireylere yönelik verdikleri hizmetlerde güçlük yaşamakta ve hizmet kaliteleri düşmektedir. Bu durum da haliyle işitme engelli öğrencileri doğrudan olumsuz etkilemektedir. Ayrıca bu tür hizmetlerden karşılaşılan diğer bir soru ise görme engelli öğrenciler ile ilgilidir. O da öğrenci işleri tarafından kendi birimleri ile ilgili yapmış oldukları duyuruları panolara asılarak duyuruları yapmaları görme engelli öğrenciler için önemli bir problem olarak belirlenmiştir.

Genel olarak engelli öğrencilerin sorun yaşadıkları bir hususta boş zamanlarını geçirecekleri sosyal ve kültürel mekânların olmayışıyla ilgilidir. Engelli öğrenciler üniversite kampüsünde boş zamanlarını değerlendirecekleri herhangi bir yaşam alanına sahip olmamaları sosyal ve kültürel anlamda verimsiz bir üniversite yaşantısına yol açmaktadır. Oysaki üniversite yılları öğrencilerin sosyalleşme ve kültürlenmeleri için son derece önemlidir. Ayrıca engelli üniversite öğrencileri arkadaşlıklar edinmede sorunlar yaşanmaktadır. Engelli üniversite öğrencileri genelde sınıflarında, kafeteryalarda ve üniversite hayatları boyunca birkaç arkadaş dışında arkadaşlık edecek birilerini bulamamakta yakınmaktalar. Arkadaşlık etmek istedikleri birçok öğrencinin engelli öğrenciden uzak kaçması, dışlaması, hor görmesi ya da acınarak yaklaşması haliyle engelli üniversite öğrencisini üzmekte ve sınırlı arkadaşlık ilişkisinin gelişmesine yol açmaktadır.

Engelli öğrencilerin üniversiteden beklentileri ise; öncelikle kendileri için fiziki mekânlara ve bilgiye erişimde eşit uygulamalarını artırılmasını talep etmektedirler. Diğer bir ifadeyle engelli öğrenciler üniversite kampüsü içindeki tüm kaldırım, bina, merdiven, lavabo, derslik gibi alanlara sorunsuz erişmek istemekteler. Ayrıca her türlü ders materyallerine, 
kütüphanelerde kolayca bilgiye erişim imkânına sahip olmak ve özellikle öğrenci işlerinde kendi ihtiyaçlarına uygun hizmet almak ve bilgilerin verilmesini istemekteler. Boş zamanlarında eğlenip dinlenecekleri, sosyalleşip kültürlenebilecekleri ortamların oluşturması, engelli bireylere yönelik farkındalığın artırılması için farkındalık çalışmalarının yapılması gibi beklentiler olduğunu belirtmiştir.

\section{Öneriler}

$\mathrm{Bu}$ araştırmanın en önemli sınırlılığı Van Yüzüncü Yıl Üniversitesi öğrencilerini kapsıyor olması ve katılımcıların kendi sorunlarını dile getirmekten çekinmiş olmalarıdır. Dolayısıyla bu araştırma, araştırma sahası ve katılımcıların verdiği bilgiler ile sınırlıdır. İleriki araştırmalarda bu tür sinırlıklar göz önünde bulundurularak araştırmanın çalışma grubu belirlenmesi önerilmektedir. Ayrıca üniversitelerdeki engelli öğrencilerin iç ve dış mekânda karşılaştığı erişim sorunlarının giderilmesi için tespit çalışmalarının yapılması, engelli öğrencilerin bilgiye erişimi için gerekli tedbirlerin alınması ve hizmetlerin artırılması, engelli öğrencilerin boş zamanlarını değerlendirecekleri sosyal kültürel alanların genişletilmesi, üniversite bünyesindeki engelli araştırma ve uygulama merkezi ile engelli öğrenciler danışma ve koordinasyon birimlerinin engelli öğrencilerin sorunlarının tespiti ve çözümünde daha aktif rol oynamaları önerilmektedir.

\section{Makalenin Bilimdeki Konumu}

Engellilik Sosyolojisi ve Özel Eğitim Bölümü

\section{Makalenin Bilimdeki Özgünlüğü}

Literatürde Türkiye'de üniversite eğitimi gören engelli öğrencilerin temel sorun ve beklentilerine yönelik yapılan alan çalışmaları yok denecek kadar azdır. Literatürde sadece bir çalışmaya rastlanılmıştır. Dolayısıyla üniversitede eğitim gören öğrencilerin temel sorun ve beklentileri ile ilgili literatürde yeterli çalışmanın olmadığı tespit edilmiştir. Bu nedenle engelli öğrencilerin üniversite eğitimi sürecinde karşılaştığı güçlükler Van yüzüncü yıl üniversitesi örneği ile inceleme ihtiyacı duyulmuştur. Bu çalışma, sosyolojik bağlamda pek incelenmemiş bir konuyu ele alması, verilerin ilk elden toplanması, çarpıcı bulgu/sonuçlara ulaşılması bakımından son derece özgül bir çalışma olmuştur. Ayrıca, sosyolojik bakış açısıyla engelli öğrencilerin üniversite eğitiminde karşılaştığı temel sorunlarına işaret ettiği için de önemli bir çalışma olmuştur. 


\section{Kaynakça}

Burcu, E. (1999). Üniversitede Okuyan Özürlü Öğrencilerin Sorunları: Hacettepe -Beytepe Kampüsü Öğrencileri Örneği. Hacettepe Üniversitesi Edebiyat Fakültesi Dergisi. 19(1). s. 83-103.

Clarke, M. M., J. Riach ve W. M. Chyne (1977). Handicapped Children and Pre-School Education, Report to the Warnock Committee on Special Education, University of Strathclde.

Cohen, L. H. (1994). Train Go Sorry-inside Deaf World. Boston: Houghton Miffiin.

Dökmen, Z. Y., ve Kışlak, Ş. T. (2004). Engelli Olan ve Olmayan Üniversite Öğrencilerinin Demografik ve Psikolojik Özellikleri ile Sorunlarının Karşılaştırılması. Kriz Dergisi, 12 (2), 33-47.

Lane, H. (1992). The Mask of Benevolence: Disabling the Deaf Community. New York: Vintage.

Mengi, A. (2014). Sosyolojik Boyutlartyla Otizm. Fırat Üniversitesi Sosyal Bilimler Enstitüsü Yayınlamamış Doktora Tezi.

Muuss, R. (1971), “The Philosophical and Historical Roots of Theories of Adolescence”, R.E. Muuss (ed.), Adolescent Behavior and Society, New York.-Random House.

ÖSYM, (2017). http://dokuman.osym.gov.tr/pdfdokuman/2017/OSYS/KILAVUZ18042017. pdf (erş.tar.: 04.11.2018).

I. Özürlüler Şurası, (1999). Çağdaş Toplum Yaşam ve Özürlüler Komisyon Raporları Genel Kurul Görüşmeleri, Ankara: Türkiye Cumhuriyetti Başbakan Özürlüler İdaresi Başkanlığgl.

Sevinç, İ., ve Çay M. (2017). "Fiziksel Engelli Bireylerin Üniversite Eğitimi Sırasında Karşılaştıkları Sorunlar (Akdeniz Üniversitesi Örneği)”, Selçuk Üniversitesi Sosyal ve Teknik Araştırmalar Dergisi, Sayı: 13, 2017, ss. 219-238.

Shapiro, J. (1993). No Pity.'People with Disabilities Forging a New Civil Rights Movements. New York: Times/Random House. 
Thomas, A. P., M.C. Bax ve D. P. Smyth (1989). The Health and Social Needs of Young Adults with Physical Disabilities, London: Mac Keith Press.

Weitz, R. (1996). The Sociology of Health, Illness and Health Care, Belmont. CA: Wadsworth.

WHO (1980), International Classification of impairments, Disabilities and Handicaps, Geneva: World Health Organisation.

Younghusband, E. (1970), Living with Handicap: Report o f a Working Party on Children with Special Needs. London: National Children's Bureau.

http://sgb.meb.gov.tr/meb_iys_dosyalar/2018_09/06123056_meb_istatistikleri_orgun_egitim _2017_2018.pdf(Erş. Tarihi: 25.10.2018)

http://yok.gov.tr/web/ engelsizyok /anasayfa. 2 Mayıs 2017’deki YÖK “Engelsiz Erişim Çalıştayı" (Erş. Tarihi: 25.10.2018)

5378 sayıl1 (2005). “Engelliler Hakkında Kanunun”, (Erş. Tarihi: 04.11.2018). 


\section{Summary}

\section{Statement of Problem}

The concept of disability is used to identify individuals whose full and active participation to the community is restricted from being on equal footing with other individuals due to their deficiencies occurring in certain proportions in their physical, mental, spiritual and sensory abilities; affected by the different attitudes and views of the society and the environment; and those who need a variety of counseling and supporting services throughout their lifecycle. In schools and colleges of the universities in Turkey, students are educated through multiple departments or majors for various specialties and professions. In Turkey, students are registered to universities according to their academic qualifications and preferences. Thus, the students can participate in a training process in accordance with the current program of the department. However, even if they are admitted on equal terms, not every single student's participation in the learning process is the same. In other words, university life and participation in education processes of each student are different. Yet, basic needs of the students studying at universities are very similar. The qualities of the universities, such as; plan, program, equipment, accessibility, being applicable for the healthy students rather than the students with disabilities and ignoring their special needs lead to more difficulties in the university life of disabled students. Therefore, this research was carried out in order to determine the problems of the students with disabilities in Van Yüzüncü Y1l University and to reveal their expectations. Thus, the research was conducted with the following two basic questions:

1- What sort of difficulties did you encounter during your university education?

2- What kind of expectations did you have during your university education?

\section{Method}

The study is a descriptive study using qualitative data collection and evaluation techniques based on qualitative research method. For the study group, purposive sampling group was chosen. The study was carried out with 25 participants, including visual, hearing, bipolar and physically handicapped students studying at different faculties and colleges in the central campus of Van Yüzüncü Y1l University. The study was conducted in a ten-month field research process. In the research, the participants`knowledge, experience, basic perceptions and approaches about the university life are collected via focus groups and in-depth interviews. 
The data obtained from the participants were decrypted and subjected to descriptive analysis. The data were evaluated in two different categories as problems and expectations. Research findings are presented in different sub-categories such as; education-instruction, nutritionhousing, accessibility-availability, academia-administrative staff and leisure time.

\section{Findings}

The findings of this research can be summarized as follows: The internal and external spaces of the central campus of Van Yüzüncü Y1l University are partly problematic for the orthopedic and visually impaired students. The fact that the instructors do not know the sign language and do not consider the situation of the hearing-impaired students during their lectures leads the students with disabilities to not benefit from the educational opportunities on equal terms in their university education. Since the visually impaired students cannot see the letterings written by the lecturer on the board and the hearing impaired students cannot take the course notes because they cannot hear the lecture, it becomes difficult for these students to have access to the course materials. In the exams, especially for students with vision, hearing and psychological problems, failure to provide readers, encoders, and any exam environments suitable for their obstacles leads to the failure of disabled students at school. Moreover, the fact that the personnel who work in the student affairs do not know the sign language leaves the students with disabilities in a difficult situation. Again, hanging out the announcements on the boards by the student affairs with regular writings is a problem for visually impaired students.

Another finding of the study is that the students with disabilities do not have any living space to spend their free time. The fact that students with disabilities are often unable to find someone to keep friends in their classrooms, in cafeterias and on the university campus, except for a few friends, causes important problems for them.

Findings about the expectations of students with disabilities from the university can be listed as follows: to increase the equal practices in accessing physical spaces and information for disabled students, to offer them access to all kinds of course materials, to have easy access to information in libraries, to offer services appropriate to their needs in student affairs, and to create environments where they can spend their free time. 


\section{Discussion and Conclusion}

By the help of Burcu's (1999) study, "Problems of Disabled Students Studying at University: Hacettepe-Beytepe Campus Students Example”, basic problems and expectations of university students are identified as; "education-instruction, nutrition-housing, accessibilityavailability, academia and administrative staff“. Significant similarities as long as discreapancies were found between the results of Burcu's research and the results of this study. In this research, it was found out that Van Yüzüncü Y1l University had a problem for the students with orthopedics and visually impaired from the accessibility of the interior and exterior spaces of the campus, not having the appropriate exam environments, not knowing the sign language of the staff serving in the student affairs and also the instructors, leaving the students in a difficult position, hanging the announcements on the boards by the students' affairs creates problems for the visually impaired students and not having living areas where the students with disabilities could spend their free time, and not being able to find enough friends in the classrooms, cafeterias and within the university. Therefore, it is recommended to carry out fixation studies in order to eliminate the access problems that students with disabilities face in and out of the university, to take necessary steps for the access of students with disabilities to information and to increase the services and to add more the social cultural areas in which the students with disabilities will spend their free time. 